\title{
【Article】
}

\section{Exploring Geographical Indications for Enhancing Micro- business as a Community-based Industry in Rural Korea}

\author{
Duk-Byeong PARK \\ Researcher, Rural Resource Development Institute, RDA, Korea \\ Sung-Gak KIM \\ Associate Professor, Yamagata University, Japan
}

\begin{abstract}
:
This study aimed to explore the geographical indications to enhance communitybased industry as a model of endogenous rural development in Korea. The economic and social impacts of using geographical indications have been tremendous since the geographical indications law was implemented in 2002, One of the major impacts was the increasing number of farm households and farming areas. Challenges remain in order to develop the community-based business such as networking with extra-local and local leadership, bottoms-up approach, product advertising, quality control and restricting the terms of protection on trademark to establish geographical indications.
\end{abstract}

\section{Introduction}

Motivated by budget constraints, public concerns, and restrictions imposed by international trade agreements, Korea is beginning to reexamine the role of agriculture in promoting rural development. Economic diversification is one of the strategies adopted by Korea to overcome the declining farm economy and farm financial crisis. Local communities have tried to develop new businesses to help offset the loss of farm jobs and associated economic activity.

Agricultural products typically have qualities derived from their place of production which are basically influenced by specific local factors, such as climate and soil. Whether a sign functions as a geographical indication is a matter of national law and public awareness.

There are four different legal concepts owing to national legal traditions and historical and economic conditions: unfair competition and passing off, protected appellations of origin, registration of geographical indications and collective certification of trademarks. Local character can be translated into intellectual property rights in rural areas through the use of geographical indications systems.

Ray's (1998)"1' model has been applied as a cultural economy framework in a case study of commodification of agricultural products by geographical indication and traditional knowledge related to rural tourism. The model suggests that a deeper understanding of a culture economy with geographical indications can be gained in consideration of the contested nature of place identity. 
The cultural economy approach to rural development now highlights the instrumental and normative deployment of heterogeneous cultural markers, such as regional foods ${ }^{(2)}$. It involves both recovery of regional distinction and the "invention of tradition ${ }^{(3)}$."

This study aimed to provide an overview and exploration of the use of Geographical Indications (GI) to enhance specialty food micro-business in rural Korea. The emphasis is on the utility of geographical indications in a culture-based industry, with the intent of modification and providing adequate protection. Two case studies were examined involving the Bosung Green Tea Project (BGTP) and the Gochang Black Raspberry Wine Project (GBRWP), located in two industrial farming regions in southern part of rural Korea, distant from the urban fringe.

\section{Rural Community Development and Geographical Indications}

Geographical indication is a resource for those seeking information about the use of names that point to a specific geographic place on agricultural and other products. A geographical indication is a sign on goods that have a specific geographical origin and possess qualities or a reputation that are due to that place of origin. Most commonly, a geographical indication consists of the name of the place or origin of the goods.

The National Agricultural Products Quality Management Service of the Korean government imposes criteria in the approval of geographical indications. The national law (Act 8 on Agricultural Products Quality Management) has provisions which are related to specific qualities or a reputation that is attributed to the place of origin. The use of Korean geographical indications in an effort to diversify rural economy is important, to help develop rural areas by promoting services, micro-enterprises, and rural tourism to the public. It is also relevant in the development of cultural heritage to improve the conditions for growth and job creation. Contemporary strategies for rural development in Korea are based upon notions of self-help and bottoms-up, community-based initiatives that are said to "empower" individuals from the imposing structures of government intervention. Some researchers ${ }^{(4)}$ have suggested that localization via niche and specialty agro-food markets holds particular promise for rural development of peripheral agricultural regions. A central question of this paper is how state, civil society, and markets can effectively work together in an increasingly globalized context to contribute towards the economic, social, cultural, and environmental health of rural areas, promoting continuity and change, diversity, and cohesion.

Ray $^{(5)}$ identified three aspects to rural development approach: territorial basis (as opposed to sectoral); use of local resources; and local contextualization through active public participation. The approach holds the prospect of "local areas assuming greater control of development by reorienting development around local resources and by setting up structures to sustain the local development momentum after the initial trials ${ }^{(6) !}$. It is posited that the incorporation of local traditional knowledge will create a network of rural development agents that can "play a stimulating, mobilizing and coordinating role."

Geographical indication is "a sign used on goods of specific geographical origin and possesses qualities or reputation due to that place of origin ${ }^{(7) !}$. Geographical indications 
"identify a good as originating in the territory (of a member), or a region or locality in that territory, where a given quality, reputation or other characteristic of the good is essentially attributable to its geographical origin" (Article 22 of GATT-TRIPs). Most commonly, a geographical indication consists of the name of the place of origin of the goods.

Geographical indications may be used for a wide variety of agricultural products. Appellation of origin was originally a French geographical indication applying to products considered to be distinctive due to a combination of traditional know-how and highly localized natural conditions ${ }^{(8)}$.

Throughout Europe there is an enormous range of great food. However, when a product acquires a reputation extending beyond national borders, it can find itself in competition with products that pass themselves off as the genuine article and take the same name ${ }^{(9)}$. In 1992 , the European Union created systems known as PDO (Protected Designation of Origin) and PGI (Protected Geographical Indication). A PDO covers the term used to describe foodstuffs that are produced, processed, and prepared in a given geographical area using recognized know-how. In the case of the PGI, the geographical link must occur in at least one of the stages of production, processing, or preparation, Furthermore, the product can benefit from a good reputation.

\section{Lists on Available Geographical Indications in KIPO}

Endogenous development approaches ${ }^{(1)}$ hold that mobilizing and generating knowledge is the critical input to development, that agglomeration of interacting actors are the sources of much of this knowledge, and that economic proximity is necessary for knowledge pools that it makes sense to target public investments to places. According to a survey on geographical indications by Korea Intellectual Property Organization (KIPO) and Korea Intellectual Property Rights Company (KIPRC), there are 342 specialty products on 70 items including categories on specialty food and handicrafts. The specialty foods are pine nuts, grape, rice, ginseng, potato, bean curd, pine mushroom, kimchi, tarrfy, dried walleye pollack, noodles, and wine. Straw mat is a sample handicraft.

The geographical indications are meant to develop and protect local specialty as well as aim to encourage diverse agricultural production, to protect product names from misuse and imitation, and to help consumers by giving them information concerning the specific character of the products. This is also to encourage and help the Korean regions to improve their relative economic performance.

\section{N Geographical Indications of Agricultural Products in Korea}

The National Law on Geographical Indications started in 1999. Since 2000, seven geographical indication products have been registered. The items registered are two kinds of green tea (Boseng Green Tea and Hadong Green Tea), wine, garlic, and pepper. The Bosung Green Tea (2000) and the Gochang Black Raspberry Wine were the first and third specialty products to be registered, respectively in Korean Geographic Information System (KGIS). 
Exploring Geographical Indications for Enhancing Micro-business as a Community-based Industry in Rural Korea

Table 1 Lists of available geographical indications in KIPO

\begin{tabular}{|c|c|c|}
\hline Region & $\begin{array}{c}\text { Number of } \\
\text { Specialty Products }\end{array}$ & Name of Products \\
\hline Kyeongi & 28 & (4) Gapyeong Pine Nuts, Ansung Grape, Icheon Ceramics,. Icheon Rice \\
\hline Incheon & 2 & (2) Ganghwa Straw Mat, Ganghwa Ginseng \\
\hline Gangwon & 88 & $\begin{array}{l}\text { (13) Daeganrung Potato, Daeganrung Uncurdled Bean Curd, Boungpyeong } \\
\text { Buckwheat, Yangyang Pine Mushroom, Odeasan KimChi, Wonju Chiak } \\
\text { Mountain Tarrfy, Jeongsun Hedysarum, Jeongsun Marble, Jinburung Dryed } \\
\text { Walleye, Chuncheon Chicken Rib, Chuncheon Nuddle, Hongchen Oksun Spirits, } \\
\text { Hengsung Genseng }\end{array}$ \\
\hline Chungnam & 50 & $\begin{array}{l}\text { (8) Gongju Jungan Chestnet, Gumsan Ginseng, Dangjin Chorando Mugwort, } \\
\text { Seosan Ginger, Seosan Garlic, Seosan Hansan Ramie Fabric, Seochen Hansan } \\
\text { Liquor, Cheongyang Dried Fruit of the Chinese Matrimony Vine }\end{array}$ \\
\hline Chungbuk & 15 & $\begin{array}{l}\text { (5) Gesan Red Hot Pepper, Boeun Jujube, Umsung Red Hot Pepper, Jechen } \\
\text { Medical Herb, Chungju Apple }\end{array}$ \\
\hline Jeonbuk & 13 & $\begin{array}{l}\text { (6) Namwon Wooden Tableware, Sunchang Red Pepper Jam, Jangsung Apple, } \\
\text { Jeonju Boiled Rice with Assorted Mixtures, Pungcheon Broiled Eels, Gochang } \\
\text { Black Raspberry Wine }\end{array}$ \\
\hline Jeonnam & 33 & $\begin{array}{l}\text { (14) Gohyung Chinese Lemon, Gurae Red Cheery, Naju Pear, Damyang Bamboo } \\
\text { Handicraft, Muan Onion, Youngam Dried Croaker, Youngam Fig, Youngam Fish } \\
\text { Eggs, Wando Dried Laver, Jindo Ginger, Jindo Green Onion, Jindo Stingray } \\
\text { Liquior, Changpyeong Rice Taffy, Haenam Sweet Potato, Bosung Green Tea }\end{array}$ \\
\hline Kyeongbuk & 45 & $\begin{array}{l}\text { (5) Andong Hemp Cloth, Andong Salted Mackerel, Punggi Ginseong, Oulrungdo } \\
\text { Pumpkin Tarrfy, Uesung Garlic }\end{array}$ \\
\hline Kyeongnam & 60 & $\begin{array}{l}\text { (6) Namhae Salted Anchovies, Masan Steamed Flogfish, Changwon Sweet } \\
\text { Persimmon, Hamyang Lacquer, Sancheong Dried Persimmon }\end{array}$ \\
\hline Jejoo & 8 & $\begin{array}{l}\text { (8) Bokjejoo Cactus, Jejoo Cutlassfish, Jejoo Mandarin Orange, Jejoo Black Pig, } \\
\text { Jejoo Gem Sea Bream }\end{array}$ \\
\hline Total & & $342(70)$ \\
\hline
\end{tabular}

Sources: 1) Korea Intellectual Property Organization (KIPO). 2003. Lists of available geographical indications products registered in KIPO.

2) National Agricultural Products Quality Management Services. 2005.

\section{Two Case Studies of Geographical Indication Products}

The new focus in rural development policy is moving from agriculture-based rural

Table 2 Geographical indications products in South Korea

\begin{tabular}{l|l|c|c|c|l|c}
\hline \multicolumn{1}{c|}{ Name } & \multicolumn{1}{|c|}{ Boundary } & $\begin{array}{c}\text { Registered } \\
\text { Date }\end{array}$ & $\begin{array}{c}\text { Number of } \\
\text { Farmers }\end{array}$ & $\begin{array}{c}\text { Number of } \\
\text { Organizations }\end{array}$ & $\begin{array}{c}\text { Products } \\
\text { Characteristics }\end{array}$ & $\begin{array}{c}\text { Farm } \\
\text { Land (ha) }\end{array}$ \\
\hline Boseong Green Tea & Boseong county & 2002 & 220 & 15 & Processed & 646 \\
\hline $\begin{array}{l}\text { Hadong } \\
\text { Green Tea }\end{array}$ & Hadong county & 2003 & 1,200 & 55 & Processed & 600 \\
\hline $\begin{array}{l}\text { Gochang Black } \\
\text { Raspberry Wine }\end{array}$ & Gochang county & 2004 & 2,154 & 7 & Processed & 484 \\
\hline Seosan Garlic & Seosan county & 2005 & 3,600 & 21 & Raw products & 422 \\
\hline $\begin{array}{l}\text { Yeongyang Red Pepper } \\
\text { Powder }\end{array}$ & Yeongyang county & 2005 & 350 & 6 & Processed & 230 \\
\hline Uiseong Garlic & Uiseong county & 2005 & 3,402 & 12 & Raw products & 1,302 \\
\hline $\begin{array}{l}\text { Goesan Red Pepper } \\
\text { Dried }\end{array}$ & Goesan & 2005 & 4,800 & 4 & Raw products & 2,000 \\
\hline
\end{tabular}

Source: Author's field survey from September, 2004 to April, 2005. 
development to broader area-based rural development. In the past, public policies tend to focus on rural areas en bloc-treating them as homogenous, with uniform problems and similar opportunities. Such an approach no longer reflects the reality of diversity in rural areas. While rural areas generally have low population density and significant agricultural land use, their development patterns are however, significantly different. As a consequence, governments recognize the need for a more locally tailored or "territorial" approach in rural development. The following presents the two case studies on Bosung Green Tea Project $(\mathrm{BGTP})^{(11)}$ and Gochang Black Raspberry Wine Project (GBRWP)(12) highlighting communitybased industry with geographical indications.

\section{1 ) Bosung Green Tea Project (BGTP)}

The BGTP is anchored in a rural development model which combines tourism and cultural traits. This is a typical example of an endogenous bottoms-up development approach with community participation. About $40 \%$ of total green tea production in Korea is from Bosung county.

Eight firms participated in the BGTP in 1996, increasing to 39 in 2004. The number of farm households participating also increased from 80 in 1996 to 537 in 2004 . The number of firms increased dramatically, after registering geographical indications in 2002.

The Bosung county is very much suited to grow tea because it is located in the southern part of Korea characterized with warm winter season. Due to geographical advantage, Kyeongsung Chemistry Company started to grow tea during the Japanese colonial era in 1939. As such, it has become a cultural heritage based on beautiful landscape and historical relevance.

(1) Socio-economic Impact

The socio-economic impacts of registering geographical indications are manifested in the following:

a. Increasing number of processing firms and high quality products. The number of participating firms revealed a dramatic increase from eight firms in 1996 to 39 in 2004. The

Table 3 Selected characteristics of the BGTP

\begin{tabular}{c|c|c|c|c}
\hline Category & Number of Firms & Number of Farm Households & $\begin{array}{c}\text { Cultivated Land } \\
\text { (ha) }\end{array}$ & $\begin{array}{c}\text { Annual Yield (dried) } \\
\text { (ton) }\end{array}$ \\
\hline 1996 & 8 & 80 & 291 & 436 \\
\hline 1997 & 8 & 85 & 311 & 466 \\
\hline 1998 & 11 & 125 & 358 & 537 \\
\hline 1999 & 13 & 137 & 392 & 588 \\
\hline 2000 & 16 & 158 & 425 & 637 \\
\hline 2001 & 19 & 160 & 446 & 691 \\
\hline 2002 & 39 & 221 & 518 & 966 \\
\hline 2003 & 39 & 274 & 551 & 966 \\
\hline 2004 & 39 & 537 & 646 & 1,131 \\
\hline
\end{tabular}

Source: Author's field survey from September, 2004 to April, 2005. 
Exploring Geographical Indications for Enhancing Micro-business as a Community-based Industry in Rural Korea

Table 4 Economic impacts of BGTP

\begin{tabular}{c|c|l}
\hline Category & Annual Income (Million US\$) & \multicolumn{1}{|c}{ Description } \\
\hline Green Tea (raw) & 13 & $425 \mathrm{ha} \times 418 \mathrm{~kg} / 10 \mathrm{a} \times 81.2 \mathrm{USD} / \mathrm{kg}$ \\
\hline Processed Green Tea & 53 & $650 \mathrm{ton} \times 81.2 \mathrm{USD} / \mathrm{kg}$ \\
\hline Processed Foods & 14 & $\begin{array}{l}\text { Drink, Noodle, Kimchi, Pork, Soybean Paste, Soybean Sauce, } \\
\text { Hot Pepper Paste }\end{array}$ \\
\hline Tourism & 54 & More than 5,000 thousand tourist \\
\hline Employment & 5 & Annual employment 192,307 persons $\times 26$ USD \\
\hline Total & 138 & \\
\hline
\end{tabular}

Source: Ministry of Agriculture and Forest (MAF), National Agricultural Products Quality Management Service (NAPQMS) . 2006. White Paper: Geographical Indications. Anyang: National Agricultural Products Quality Management Service. pp. 25-28.

number of participating farm households also increased from 80 in 1996 to 537 in 2004 . The production of high quality products was increased by $74.6 \%$, from 20 tons in 2001 to 35 tons in 2003.

b. Rising product price and total sales. The price of raw green tea increased by a maximum of $150 \%$ and total sales also increased by $75.7 \%$.

c. Substituting rice with tea and increasing rural tourists. Farmers on this area have substituted rice with tea plant, partly as a consequence of government agricultural policy. Many farmers and other rural entrepreneurs have been exploring new ways of using their resources to counter rural problems that include innovative activities such as agri-tourism, quality production, and cultural landscape management. Local and national governments have been developing policies designed to support these new activities.

The Bosung tea plantations are one of the most famous tourist destinations in Korea. Many tourists have visited the area and bought products of geographical indication. Tourists increased by $16 \%$ from 3,490 thousand to 4,050 thousand in 2004 . Total economic benefits amounted to US\$118 million. The income from tourism in particular amounted to US\$54 million with more than 5,000 tourists visiting this area. Annual employees totaled 192,307 persons.

There is a need to enrich the community people in a sustainable way, including how to successfully combine economic benefits with the preservation of cultural and natural heritage, and developing a fulfilling, mutually beneficial relationship between community people and rural tourists.

\section{(2) Challenges}

Lack of raw materials, quality control problem, and low level of public awareness of trademark on geographical indications are the challenges being faced by the BGTP.

a. Lack of raw materials

Although the participating firms have their own land in producing green tea, some firms have not been successful in processing tea products because of the lack of raw materials. The inadequate supply is compensated through outsourcing from outside of the county. This is one of reasons why PGI should be divided into PDO and PGI.

b. Quality control problem 
Quality in relation to regional specialty food products (SFPs) including geographical indications products is defined by making reference to other socially constructed and valueladen concepts such as "authentic", "healthy", and "traditional". It is because food quality may be signified through association with particular places or regions. Some farmers were encouraged to manage their own processing company as a result of increasing product sale. They were faced however, with the problem of product quality control because of inadequate knowledge.

c. Low level of public awareness on geographical indications

The level of public awareness remained low even though the central and local governments have initiated advertising geographical indications. Some of the firms have also tried advertising their own brand to raise public awareness about geographical indications products.

d. Building community capacity and local partnership

Community people should build local partnership capacity and promoting skills acquisition to help mobilize local potential and promote private-public partnership. It has been shown that promoting cooperation and innovation could encourage entrepreneurship and promote inclusiveness and provision of local services.

\section{2 ) Gochang Black Raspberry Wine Project (GBRWP)}

The GBRWP is another rural development model aimed at enhancing community-based industry in rural Korea. After decentralization in 1993, county and local governments started facilitating activities to enhance small businesses based on local characters.

(1) Trends on size of land, number of households and total yield

Two firms joined GBRWP in 1999 which later increased to seven in 2004. Total farm size of black raspberry dramatically increased from 23 ha in 1999 to 484 ha in 2004 . The number of farm households was 2,154 in 2004.

(2) Total raw raspberry purchases (2004)

One of the main problems is the shortage of raw materials wherein only $30 \%$ of the needed raw materials can be sourced within the county and the remaining $70 \%$ of raw materials were from outside of the county.

(3) Geographical indications products certificate

Table 5 Selected characteristics of the GBRWP

\begin{tabular}{c|r|r|r|r|r|r}
\hline Category & \multicolumn{1}{|c|}{1999} & 2000 & 2001 & 2002 & 2003 & 2004 \\
\hline Size of Farming (ha) & 23 & 35 & 70 & 150 & 302 & 483 \\
\hline Number of Firms & 2 & 2 & 3 & 4 & 7 & 7 \\
\hline Number of Farm Households & 172 & 238 & 410 & 740 & 1,620 & 2,154 \\
\hline Total Yield (ton) & 60 & 100 & 140 & 320 & 600 & 780 \\
\hline
\end{tabular}

Note: The data from author's field survey from September, 2004 to April, 2005. 
Table 6 Total raw raspberry purchases of GBRWP

\begin{tabular}{c|c|c|c}
\hline Name of Firms & Total Purchases & Within County & Other County \\
\hline $\begin{array}{c}\text { Sununsan Special Wine } \\
\text { (Hongjin) }\end{array}$ & 800 & 100 & 700 \\
\hline Gochang Specity & 300 & 250 & 50 \\
\hline Gochang Goindol & 130 & 27 & 103 \\
\hline Total & 1,230 & 377 & 853 \\
\hline
\end{tabular}

Source: Author's field survey from September, 2004 to April, 2005.

Table 7 Total production of "Bosung Green Tea”

\begin{tabular}{c|r|r|r}
\hline \multirow{2}{*}{ Category } & \multicolumn{3}{|c}{ Unit: bottle } \\
\cline { 2 - 3 } & \multicolumn{1}{|c|}{$500 \mathrm{~m} \ell$} & $700 \mathrm{~m} \ell$ & \multirow{2}{*}{ Total } \\
\hline Gochang Specialty Black Raspberry Wine & 3,384 & 1,110 & 4,494 \\
\hline Gochang Goindol Black Raspberry Wine & - & 640 & 640 \\
\hline Total & 3,384 & 1,750 & 5,134 \\
\hline
\end{tabular}

Source: Author's field survey from September, 2004 to April, 2005.

Two firms were producing geographical indications products and one of the firms, the Sununsan Specialty Corporation (SSC), could not get a certificatation because of raw materials outsourcing and raw materials mixture. Only $5-6 \%$ of the products can be certified as geographical indications. The Korea Taxation Department is responsible in inspecting product quality because of the tax being charged to the products based on alcohol degree.

(4) Challenges

Revitalizing local agri-food communities in rural agro-industrial regions is particularly challenging. In reality, local people complain about the "top-down" approach wherein the central government exercises tight control and sets strict parameters.

a. Inadequate raw material supply

After registering geographical indications, member farmers called for higher price than before. The price of raw materials increased from US $\$ 6 / 1 \mathrm{~kg}$ to US $\$ 6.3 / 1 \mathrm{~kg}$. Retail sales of member farmers were increasing and they earn more money than selling to wholesale firms. It has been shown that firms should consider benefit distribution and collaboration with member farmers.

b. Lack of advertisement and low profit

Consumers' perception on geographical indications is not sufficient because of lack of advertisement. Producers were required to advertise their products, especially geographical indications. While increasing incomes is anticipated by farmers and local firms, the actual incomes did not match the anticipated income.

c. Deficiency of networking with extra-local institutions

Local stakeholders put emphasis in the creation of extra-local institutions to protect and valorize local knowledge. Moreover, it is important to show how local knowledge as a geographical indication can be cultivated through the process of association. However, 
partnership is not working even though it offers many advantages to rural development including local sensitivity, increased funding opportunities, wider public participation, and reduction of inter-agency conflict.

d. Promoting entrepreneurship and encouraging rural tourism

There is a need to develop micro-business and crafts, which can build on traditional skills, develop new competencies, help promote entrepreneurship and develop the economic fabric. Moreover, training young people in the needed skills is beneficial the local economy. Community people should raise economic activity and employment rates in the wider rural economy and create a better territorial balance in both economic and social terms such as rural tourism, crafts, and the provision of rural amenities.

\section{Conclusion}

In an increasingly globalized food economy, local agri-food initiatives are promoted as more sustainable alternatives, both for small-scale producers and ecological conscious consumers. The new focus in rural development policy implies moving from agriculture-based rural development to broader cultural-based rural development. The community-based industry is one of the strategies, indicative of an advanced liberal form of community governance. The geographical indications were set up by the Korean national government promoting sustainable economic development. According to Korea's experiences on facilitating and registering geographical indications, there are several recommendations for enhancing community economic development and revitalization.

First, geographical indications used for agricultural products could highlight specific qualities of product, influenced by specific local factors such as climate and soil as found in the two case studies on geographical indications presented herein.

Second, within these areas, national and local policies have often concentrated on trying to encourage "bottoms-up" development revolving around the commodification of local cultural resources. The system of geographical boundary to protect intellectual property rights should be more flexible because in some cases intellectual property rights is obscure and many counties have their own property rights.

Third, it is necessary for trademarks to restrict their terms of protection to establish geographical indications. It is because geographical indication is not quality certification but protecting intellectual property rights. Moreover, it has been shown that the qualification of applicants had to expand not only organization but also individuals living in their areas. Advanced countries with geographical indications such as France and Italy are not exclusive for people who live in their local areas.

Fourth, it was emphasized that the certification of quality was divided into Protected Geographical Indication (PGI) and Protected Designation of Origin (PDO) to differentiate product quality and nurturing community-based industry. At present, Korea's geographical indication is only PGI, not PDO. If PDO is available, consumers' trust in products with geographical indications will increase. An appellation of origin is a special kind of geographical indication, used on products with specific quality that is exclusively or 
essentially due to the geographical environment in which the products are produced. The concept of geographical indication encompasses appellations of origin.

Fourth, to develop geographical indications product with local character, community people need to organize and control the process of production. Working with the principle of empowerment, the local community is seen as an important source of knowledge and ability that can be used in development. This is a bottoms-up locally based approach. Such approach requires a process that builds on local strength and promotes community participation and leadership, as well as ownership of both the problems and the solutions.

Fifth, there is social responsibility that will ensure that the benefits go to the farmers and to those who are most in need, including the involvement of the community in planning, the empowerment of villagers in the development of tourism enterprises, and the creation of systems to ensure the equitable distribution of profits.

In conclusion, it is assumed that endogenous development and entrepreneurship are latent in rural areas and that specific measures to encourage them are needed in order to bring out local dynamics of business creation and development. Community empowerment is one of the important things to be achieved to be successful in community-based business. Even though the firms have registered their geographical indication products in the Ministry of Agriculture and Forestry (MAF), they have not been successful in their business because of the insufficient willingness and belief to empower their communities.

\section{Notes}

(1) Ray, C. 1998. Culture, intellectual property and territorial rural development. Sociologia Rualis 38 (1): 3-20.

( 2 ) Bessiere, J., 1998. Local development and heritage: Traditional food and cuisine as tourist attractions in rural areas. Sociologia Ruralis 38 (1): 21-34.

Kneasey, M., Illbery, B., and Jenkins, T. 2001. Exploring the dimensions of cultural economies in rural West Wales. Sociologia Ruralis 41 (3): 296-310.

Ray, C. 1998. Ibid. Pp. 3-20.

( 3 ) Hobsbawm, E., and Ranger, T. (Eds.). 1983. The invention of tradition. Cambridge, England: Cambridge University Press.

( 4 ) Ilbery, B. and Kneafsey, M. 1999. Niche markets and regional specialty food products in Europe: Towards a research agenda. Environment and Planning A 31: 2207-2222.

Kneasey, M., Illbery, B., and Jenkins, T. 2001. Ibid. Pp. 296-310.

( 5 ) Ray, C. 1999. Towards a meta-framework of endogenous development: Repertoires, paths, democracy and rights. Sociologia Ruralis 39(4): 522-537.

( 6 ) Ibid. p. 528.

( 7 ) WIPO, 2005. http://wipo.int/en/ip_business/collective_marks/geographical_indications.htm

( 8 ) Moran, W. 1993. Rural space as intellectual property. Political Geography 12 (3): 263-277.

( 9 ) Europa. 2005. http://europa.eu.int/pol/agr/index_en.htm

(10) Hinrichs, C. C. 2003. The practice and politics of food system localization. Journal of Rural Studies 19: 33-45.

van der Ploeg, J. D. Renting, R., Brunori, G., Knickel, K., Mannnion, J., Marsden, T., Roest, K., Guzman, E. S., and Ventura, F. Rural development: From practices and policies towards theory. 
Sociologia Ruralis 40 (4): 391-408.

(11) Bosung Green Tea Company. 2005. http://www.bosunggreentea.com/sub_01.html

(12) Gochang Bokbunja Company.2005. http://gochangbokbunja.com/center/company2.html

Address:

Duk-Byeong Park

Rural Resource Development Institute,

Rural Development Administration

Suwon, KyeongGi 441-853, KOREA

Associate Prof. KIM, SungGaK

Faculty of Agriculture, Yamagata University

Tsuruoka, Yamagata Japan 997-8555

\section{【論文】}

文化基盤産業としての小規模郷土産業育成のための地理的表示制度に関する研究 一韓国農村を事例として一

韓国・農村振興庁・莀村資源開発研究所 朴 德秉 - 山形大学 金 成㙾 